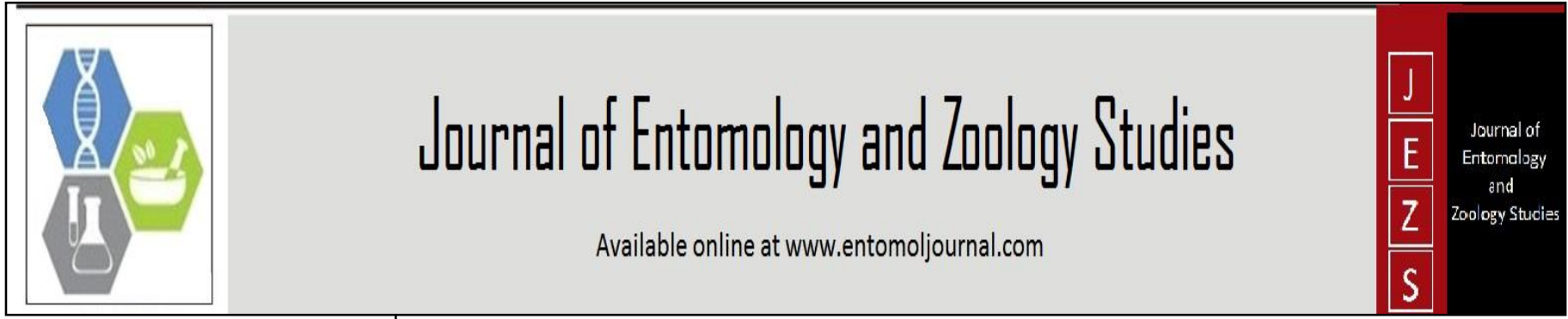

E-ISSN: 2320-7078

P-ISSN: 2349-6800

www.entomoljournal.com

JEZS 2020; 8(6): 1918-1923

(C) $2020 \mathrm{JEZS}$

Received: 17-09-2020

Accepted: 23-10-2020

B Mondal

Ph. D. Research Scholar,

Department of Aquaculture,

Faculty of Fishery Sciences,

West Bengal University of

Animal and Fishery Sciences, 5,

Budherhat Road, Panchasayar,

Chakgaria, Kolkata, West

Bengal, India

\section{SK Das}

Professor, Department of

Aquaculture, Faculty of Fishery

Sciences, West Bengal University

of Animal and Fishery Sciences,

5, Budherhat Road,

Panchasayar, Chakgaria,

Kolkata, West Bengal, India
Corresponding Author:

\section{SK Das}

Professor, Department of

Aquaculture, Faculty of Fishery

Sciences, West Bengal University

of Animal and Fishery Sciences,

5, Budherhat Road,

Panchasayar, Chakgaria,

Kolkata, West Bengal, India

\section{Histopathological studies of tilapia (Oreochromis mossambicus) gastro-intestinal system exposed to Castor bean seed as piscicide compared with Mohua oil cake as haemotoxic agent}

\section{B Mondal and SK Das}

DOI: https://doi.org/10.22271/j.ento.2020.v8.i6z.8104

\section{Abstract}

Histopathological manifestation of castor bean seed as fish toxicant upon gastro-intestinal system of Tilapia (Oreochromis mossambicus) was investigated parallel with mohua oil cake as haemotoxic piscicidal agent in outdoor experimental tanks. Castor seed bean was proved to be an effective piscicide with activity potential comparative with mohua oil cake though the mortality rate was higher and quicker in the later. As plant derived toxicant castor bean exhibited strong histopathological lessions in intestinal mucosa and liver whereas, mohua oil cake exhibited severe respiratory distress to the test fish. Significant reduction of dissolved oxygen and concurrent increase in $\mathrm{BOD}_{1}$ of water under both the piscicides aggravated the distress of the test fish.

Keywords: Histopathology, haemotoxic, intestinal mucosa, Oreochromis mossambicus.

\section{Introduction}

Plants are considered as the pillars of structurally diverse bioactive substances as many of them contain compounds that have insecticidal, pesticide and molluscicidal properties. These compounds are preferred over the synthetic chemical pesticides as they may result harmful residual footprints in the aquatic environment ${ }^{[1]}$. Besides, chemical piscicides have several environmental consequences variable with their relative persistency in aquatic ecosystem. Moreover, they are costly and often limited in supply. On the other hand, there are many naturally occurring plant derivatives which have been effective piscicides in use in tropical freshwater aquaculture.

Mohua oil cake is the remains following extraction of oil from the seeds of Bassia latifolia that is widely used as piscicide in carp aquaculture practices in India. Triterpenoid saponin is the principle active compound responsible for the toxic effect of mohua oil cake besides little amount of tannins, alkaloids and cyanogens. Saponin is a steroid or triterpenoid glycoside, which are large, diverse group of mainly plant-derived compounds ${ }^{[2]}$. Saponins destroy red blood cells and therefore, reduce oxygen uptake, alter haemoglobin concentrations ${ }^{[3]}$ and might also damage the gills of aquatic organisms ${ }^{[4]}$.

Originated from tropical Africa, Castor bean (Ricinus communis) is presently being cultivated as an oil seed crop and ornamental plant as well in many countries of Asia, Central and North America, Africa and Europe ${ }^{[5]}$. The toxicity of Ricinus seed has been recognized for long ${ }^{[6,7]}$. The castor bean contains $40 \%$ oil, $1 \%-5 \%$ ricin and $0.3 \%-0.8 \%$ ricinin ${ }^{[8]}$ and also a group of closely related toxic glycoproteins, ricinoleic acid (12-hydroxyoleic acid) and the alkaloid ricinin. The toxic effect of pressed Ricinus communis seeds may be due to the naturally occurring lectin, ricin ${ }^{[9]}$. Ricin is a cytotoxic protein, and its toxicity results from the inhibition of protein synthesis that leads to cell death ${ }^{[6]}$. Mondal and Das (2019) ${ }^{[10]}$ in a comparative study of mohua oil cake and castor bean seed as piscicides for one identical dose of $250 \mathrm{mg} \mathrm{L}^{-1}$ on tilapia and panchax observed a delayed response of castor bean seed compared to mohua oil cake as first and total mortality of tilapia was encountered at fourth and tenth hour of application, against twenty six hour and forty two hour in panchax respectively.

Histological observation has long been recognised as an effective approach for assessing toxicity in a number of animals. There is a clear correlation between pathological condition of cell or tissue and its affected functions ${ }^{[11-13]}$. Studies on histological observations provide 
functional data regarding the changes in cellular or sub cellular structure of an organ much earlier than external manifestations. Oreochromis mossambicus exposed in aqueous leaf extracts of Carica papaya and Nerium oleander showed histopathological changes in the tissues viz. shrunken and narrow secondary gill lamellae, mild to moderate infiltration of inflammatory cells in the primary and secondary gill lamellae; vacuolar degeneration of epithelial cells of intestinal villi, massive infiltration of inflammatory cells throughout the base of the villi and disruption of epithelial cells; swollen nucleus, hydrated and vacuolar degeneration of hepatocytes and mild pockets of infiltration of inflammatory cells in liver ${ }^{[14]}$. According to (Alim and Matter, 2015) ${ }^{[15]}$ fish gills exposed to a sublethal dose of $0.07 \mathrm{~g} / \mathrm{l}$ Argel (Solenostemma argel) showed bending of secondary lamellae, telangectiasis, cellular hyperplasia of primary filament, shortening of secondary lamellae, pyknosis, and necrosis of secondary lamellae. According to (Mosleh and Afifi, 2013) ${ }^{[16]}$, when Oreochromis niloticus intoxicated with different concentration $(1 / 3,1 / 10$ and1/20 of LC50) of tea seed cake whose active component is saponin, the histological examination of the hepatopancreatic tissue showed a severe vacuolization with pyknotic nuclei and intravascular hemolysis, necrosis with lymphocytes at the $1 / 3$ LC50 concentration; with 1/10 LC50 a moderate vacuolization in the hepatocytes and intravascular hemolysis were occurred and with 1/20 LC50; a centrolobular hydropic degeneration with pyknotic nuclei and mild intravascular hemolysis were manifested. In another toxicological study Tea Seed Cake on different organs of Oreochromis niloticus. (El-Murr et al., 2014) ${ }^{[17]}$ revealed that the intestine showed clear enteritis represented by mucinous degeneration in the mucosa and leukocyte infiltrations in the submucosa besides sloughing and necrotic apical parts of the villi and sometimes, showed focal mucosal necrosis infiltrated with lymphocytes and inflammatory oedema in the submucosa in $1 / 3$ concentration; extensive desquamation and inflammatory cells in its lumen and mild mucinous degeneration in the lining epithelia in 1/10 concentration and mild mucinous degeneration in the lining epithelia with no evidence of leukocyte infiltrates in 1/20 concentration of 96 hour LC50 concentration.

Though the use of mohua oil cake has been popularised widely, it is becoming costlier day by day and the availability of its purest and fresh form is becoming difficult. Contrary to this, the application of Ricinus communis as a whole plant or in parts is highly promising as an effective low cost piscicides ${ }^{[10]}$. However, literatures on the later as piscicide in freshwater aquaculture and its toxic histopathological manifestation in different tissues of fish is extremely scarce. Therefore, the present study has been warranted to investigate the potential of castor seed as piscicide and its histopathological manifestation in liver.

\section{Materials and methods}

The present study was conducted in the outdoor experimental facilities of the Department of Aquaculture, Faculty of Fishery Sciences, West Bengal University of Animal and Fishery Sciences, Chakgaria, Kolkata $\left(22^{\circ} 28^{\prime} 46^{\prime \prime} \mathrm{N}\right.$ and $\left.88^{\circ} 24^{\prime} 4^{\prime \prime} \mathrm{E}\right)$. Comparative piscicidal impact of two plant derived toxicants viz. powdered form of mohua oil cake (MOC) and castor bean seed (CBS) was tested in outdoor experimental tanks in which Oreochromis mossambicus was used as test fish. As MOC is a proven haemotoxic compound and there is plenty of literature upon the effect on the histopathology of different tissue of fish due to saponin (toxic component of mohua oil cake) intoxication, in this experiment only the histological changes due to castor bean seed was examined.

\section{Experimental set up}

Nine outdoor cylindrical cement cisterns $(\sim 300 \mathrm{~L}$, diameter: $62 \mathrm{~cm}$, height: $100 \mathrm{~cm}$, area: $302 \mathrm{~cm}^{2}$, water depth: $\left.1 \mathrm{~m}\right)$ were provided with $15 \mathrm{~cm}$ soil base and filled with ground water. Cow manure@ $5000 \mathrm{~kg} \mathrm{ha}^{-1}$ (155 g cistern $\left.{ }^{-1}\right)$ was applied to each of the cisterns as practiced in the pre-stocking pond preparation of Indian major carp nursery ${ }^{[18]}$. The cisterns were applied with agricultural lime @ $200 \mathrm{~kg} \mathrm{ha}^{-1}$, following seven days of cow manure application and were grouped into three batches in triplicate following a randomized block design (RBD). They were covered by fine mosquito net ( 2 $\mathrm{mm}$ mesh) to avoid entry and breeding of insects; kept undisturbed for another seven days till the water colour changed to greenish indicating development of planktons. Fifteen healthy fry of Oreochromis mossambicus $(1.55 \pm 0.3$ g) were stocked each in the first (T1), second (T2) and third (C) batches of cisterns fitted with nylon net ( $2 \mathrm{~mm}$ mesh) enclosures at $20 \mathrm{~cm}$ above the bottom surface for easy removal of the dead fishes out of toxicity. The fish were reared for five days for acclimatization and on the sixth day, powdered MOC collected from local market and was applied @ $250 \mathrm{mg} \mathrm{l}^{-1}$ in the cisterns of $\mathrm{T} 1$, whereas, air dried and powdered CBS was applied in T2 $\left(250 \mathrm{mg} \mathrm{l}^{-1}\right)$ and the third batch which was not subjected to any treatment acted as control group. The required amount of both MOC and CBS were mixed with water from the respective cisterns and were evenly broadcasted over the surface water. The water was agitated thoroughly following application of either of the toxicants with the help of a split bamboo stick.

\section{Physico-chemical parameters of water}

Selective water quality parameters like temperature, $\mathrm{pH}$, total alkalinity, hardness, dissolved oxygen and $\mathrm{BOD}_{1}$ were measured immediately after addition of the toxicants and at termination of the experiment following the methods of APHA (1995) ${ }^{[19]}$. Ammonia-nitrogen $\left(\mathrm{NH}_{3}-\mathrm{N}\right)$ and nitratenitrogen $\left(\mathrm{NO}_{3}-\mathrm{N}\right)$ were also measured using spectro-photometric method through a double beam UVVis-spectrophotometer (CECIL CE-4002) following the methods of EPA, $2009^{[20]}$. The water temperature was recorded using a centigrade thermometer (Hanna HI98127) and $\mathrm{pH}$ of water samples was measured using a digital $\mathrm{pH}$ meter (Systronics-VI).

\section{Collection of samples for histopathology}

Tissue samples of liver and intestine of the test fish were collected from CBS treatment randomly from each tank for histopathological studies.

\section{Analyses of sample}

Tissue samples of fish were fixed in Bouin's fixative for 72 hours after which they were transferred to $70 \%$ ethyl alcohol and kept overnight. Histopathological analysis was made as described by Roberts (2001) ${ }^{[21]}$ and the slides then examined microscopically.

\section{Results}

Behavioural changes of the test fishes

The test fish showed extreme agitating movement and tended 
to jump out of the culture systems under MOC treatment against CBS treatment in which the test fishes became lethargic and showed tendency to settle at the bottom, frequenting the surface rarely. Slowly the fishes attained moribund stage with decreasing activity (Fig. 1).

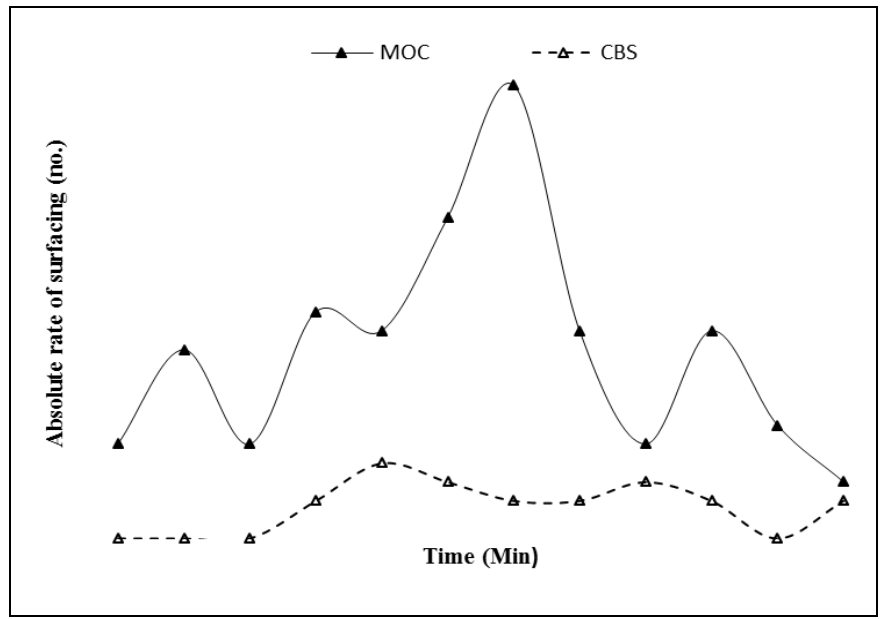

Fig 1: Absolute rate of surfacing of Oreochromis mossambicus in MOC and CBS treatment.

\section{Mortality}

Distinctly different trends of mortality of the test fish was observed in the two toxicants tested as piscicides (Fig. 2). Hourly mortality recorded showed that first $20 \%$ of the stocked test fish occurred within first hour of MOC whereas, it occurred after four hours in CBS treatment. Further, $50 \%$ of the test fish died within 3.5 hours of MOC application (T1) against 6.5 hours of CBS application (T2).

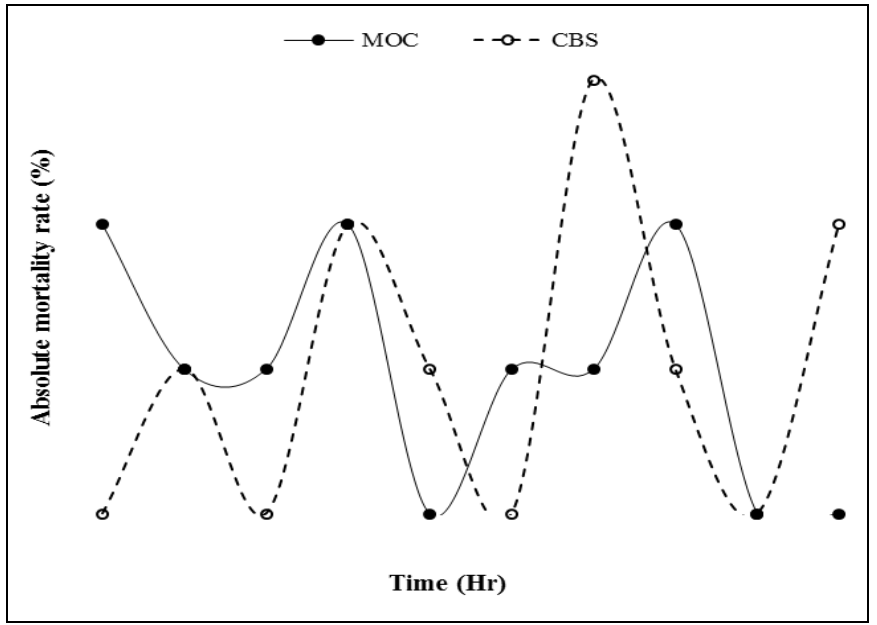

Fig 2: Absolute mortality rate of Oreochromis mossambicus in MOC and CBS treatment.

\section{Histological changes in fish liver and intestinal tissue}

In photomicrography, histopathological changes of liver tissue of Oreochromis mossambicus exhibited that, compared to the liver tissues in control group (Fig. $3 \mathrm{H} 1 \mathrm{a}$ ), the liver tissues of under CBS treatment lost normal tissue structure with basophilic reaction (Fig. $3 \mathrm{H} 1 \mathrm{~b}$ ).

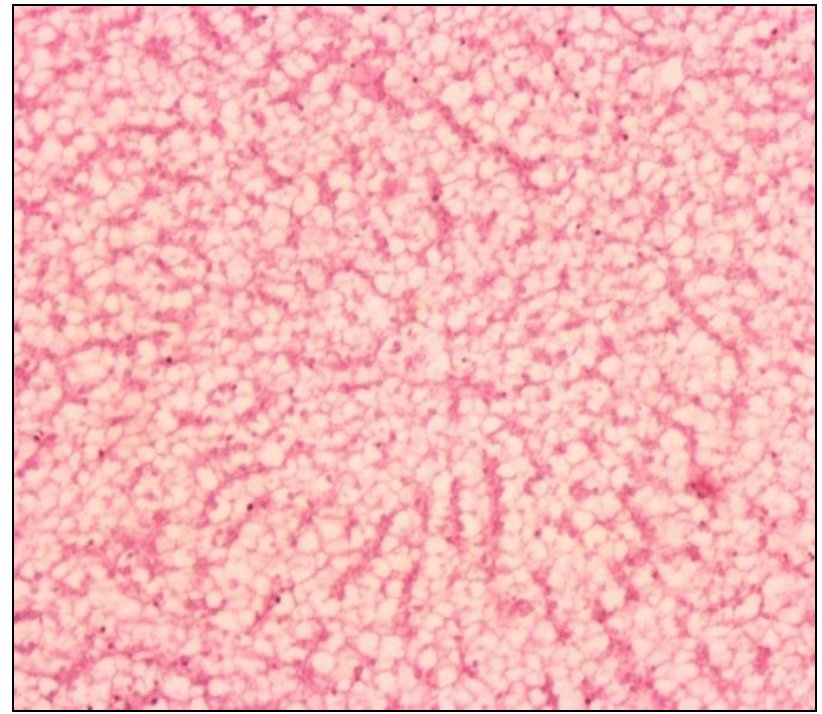

H1a

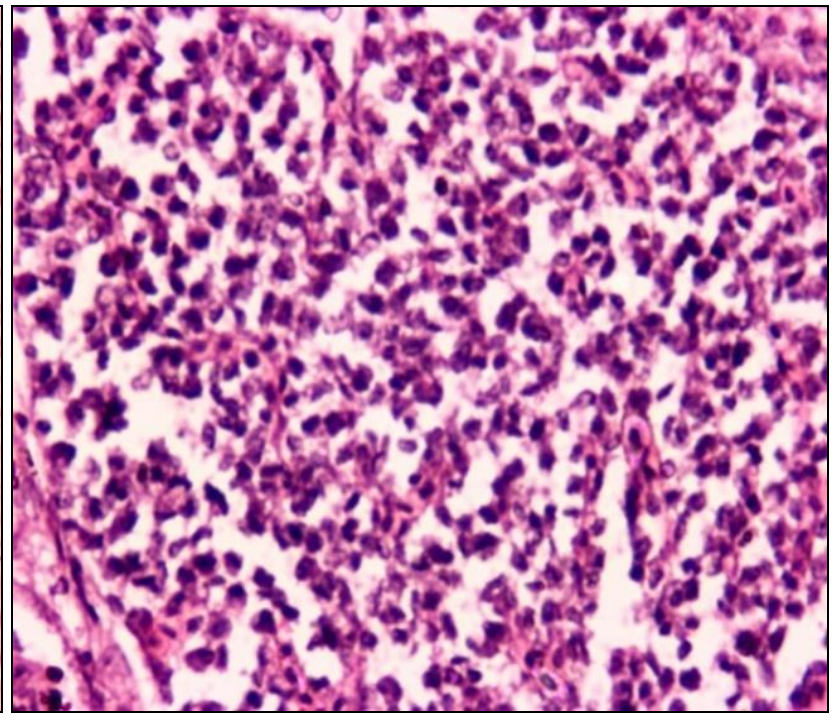

H1b

Fig 3: H1a. Photomicrography of the liver tissues of Oreochromis mossambicus in control (X 200 H\&E staining). H1b: Photomicrography of the liver tissues of Oreochromis mossambicus under CBS treatment (X $200 \mathrm{H} \& \mathrm{E}$ staining).

Compared to the intestinal tissue of Oreochromis mossambicus in control photomicrography of the intestinal tissues under CBS treatment showed degenerated mucous layer (DM) and severe intra-intestinal haemorrhagic agglutination (HA) (Fig. 4). 


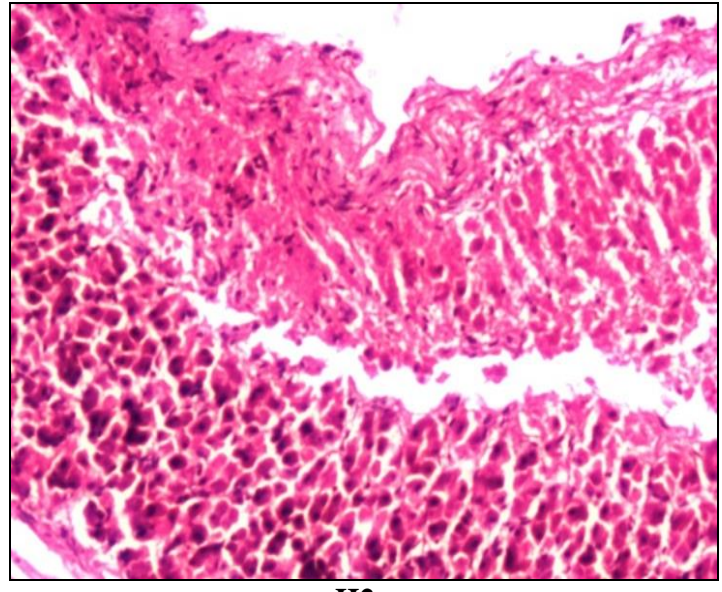

H2a

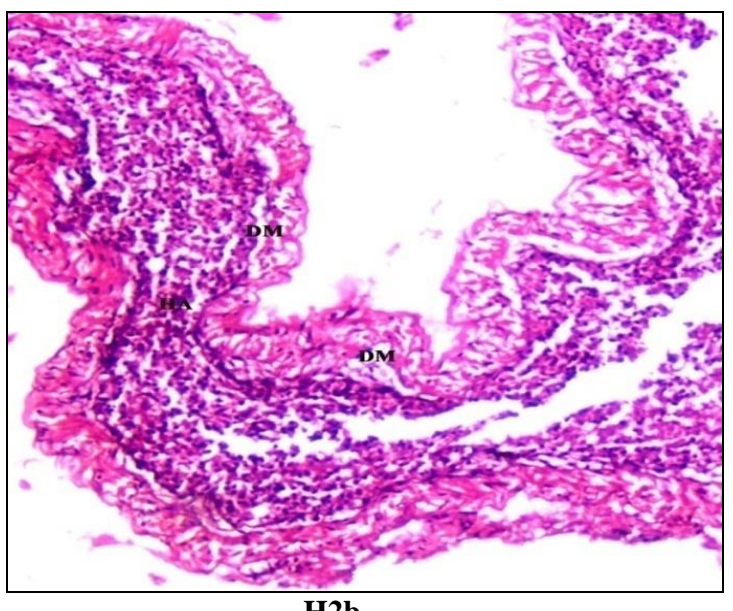

H2b

Fig 4: H2a. Photomicrography of the intestinal tissues of Oreochromis mossambicus in control (X $200 \mathrm{H} \& \mathrm{E}$ staining). H2b: Photomicrography of the intestinal tissues of Oreochromis mossambicus under CBS treatment (X $200 \mathrm{H} \& \mathrm{E}$ staining).

\section{Water quality parameters}

Minor variations in the water quality parameters were noticed except dissolved oxygen and $\mathrm{BOD}_{1}$ among the treatments
(Table 1). Except dissolved oxygen, all other parameters were within the tolerable limits.

Table 1: Water quality parameters in different treatment

\begin{tabular}{|c|c|c|c|c|}
\hline \multirow{2}{*}{ Parameters } & \multirow{2}{*}{ Phase } & \multicolumn{3}{|c|}{ Treatments } \\
\cline { 2 - 5 } & & T1 & T2 & C \\
\hline \multirow{2}{*}{ Temp. $\left({ }^{\circ} \mathrm{C}\right)$} & Initial & 26 & 26 & 26 \\
\cline { 2 - 5 } & Final & 26.5 & 26.5 & 26.5 \\
\hline \multirow{2}{*}{ Water $\mathrm{pH}$} & Initial & 7.83 & 7.81 & 7.8 \\
\cline { 2 - 5 } & Final & 7.8 & 7.78 & 7.76 \\
\hline \multirow{2}{*}{ Alkalinity $\left(\mathrm{mg} \mathrm{l}^{-1}\right)$} & Initial & 312.86 & 318.33 & 318.33 \\
\cline { 2 - 5 } & Final & 308.67 & 311.67 & 317.87 \\
\hline \multirow{2}{*}{ Hardness $\left(\mathrm{mg} \mathrm{l}^{-1}\right)$} & Initial & 670.67 & 668.67 & 668 \\
\cline { 2 - 5 } & Final & 678.67 & 676.67 & 670.67 \\
\hline \multirow{2}{*}{ DO $\left(\mathrm{mg} \mathrm{l}^{-1}\right)$} & Initial & 6.17 & 6.04 & 6.23 \\
\cline { 2 - 5 } & Final & 3.25 & 3.12 & 6.18 \\
\hline \multirow{2}{*}{ BOD $\left(\mathrm{mg} \mathrm{l}^{-1}\right)$} & Initial & 1.13 & 1.33 & 1.22 \\
\cline { 2 - 5 } & Final & 1.76 & 1.65 & 1.28 \\
\hline \multirow{2}{*}{ Ammonia-N $\left(\mathrm{mg} \mathrm{l}^{-1}\right)$} & Initial & 0.052 & 0.050 & 0.049 \\
\cline { 2 - 5 } & Final & 0.053 & 0.052 & 0.498 \\
\hline \multirow{2}{*}{ Nitrate-N $\left(\mathrm{mg} \mathrm{l}^{-1}\right)$} & Initial & 0.219 & 0.234 & 0.22 \\
\cline { 2 - 5 } & Final & 0.22 & 0.245 & 0.223 \\
\hline
\end{tabular}

\section{Discussion}

The results of the study indicated that MOC as strong haemotoxic fish toxicant resulted in instant mortality of the test fish as evident from the cumulative surfacing rate and rate of mortality. Because of suffocation, the test fish in $\mathrm{T} 1$ had to surface more and more compared to the fish in T2 which was evident from the fitted relationship of the cumulative rate of surfacing of the fish in each treatment as the time progressed following addition of the toxicants (Fig. 5).

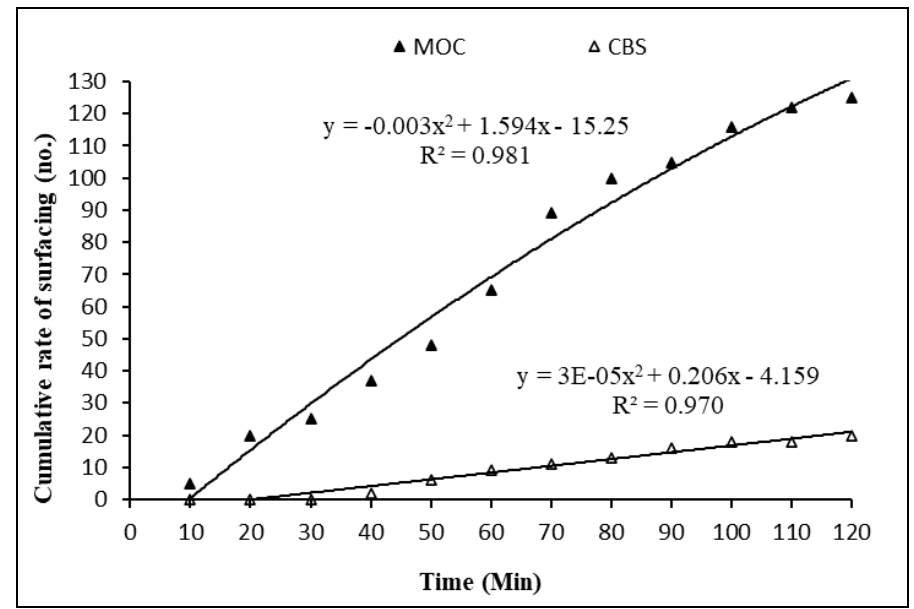

Fig 5: Fitted relationship of the cumulative rate of surfacing of Oreochromis mossambicus with time in MOC and CBS treatment. $\sim 1921 \sim$ 
Such intense respiratory distress caused by the MOC was reflected in the fitted trend of cumulative mortality rate of the test fish with time which was distinctly different from the
CBS treatment (Fig. 6) where the principal toxic effect was manifested in the gut (Fig. 3, 4). Therefore, the initial rate of mortality was delayed in CBS treatment.

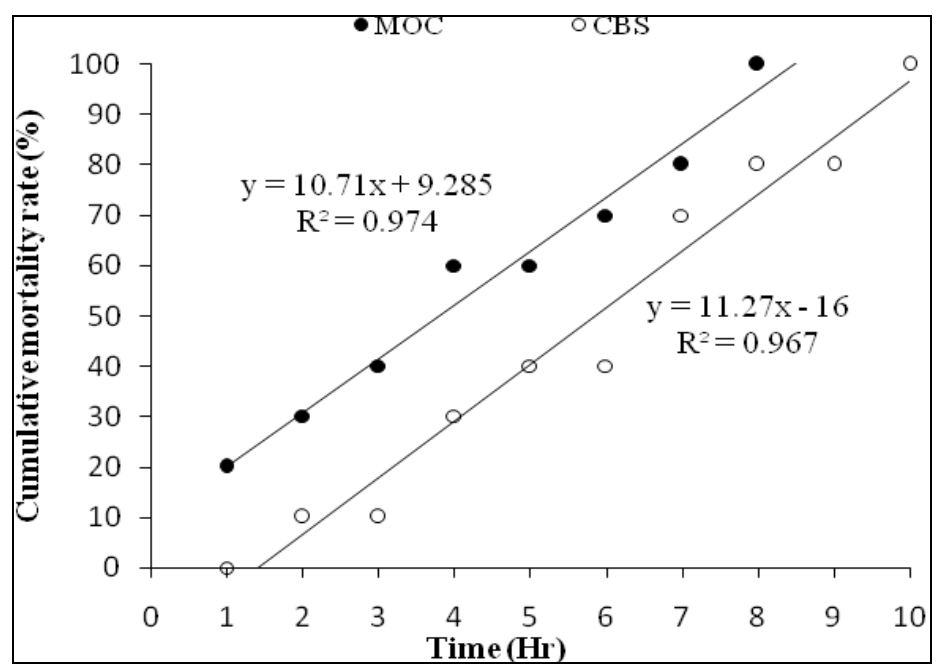

Fig 6: Fitted relationship of the cumulative mortality rate of Oreochromis mossambicus in MOC and CBS treatment with time.

This indicated that strong respiratory suffocation occurred in MOC treatment against neuro-pathological and respiratory manifestations of the test fishes under CBS treatment. The haemotoxic effect of MOC in fish model was well established by Sarkhel and Das (2005) ${ }^{[22]}$.

Though the histopathological manifestation of CBS upon liver tissue of the test fish was mild exhibited with intense basophilic reaction, it was severe in the intestinal tissues (Fig. $3,4)$. The toxic ingredient severely damaged the intestinal mucosa resulted in internal haemorrhages that resulted in occurrence of clotted blood within the lumen of the intestine manifested as haemorrhagic agglutination. The present findings with fish were somewhat different with higher vertebrates so far the toxicity of CBS is concerned. Hassan et al. (2016) ${ }^{[23]}$, in their acute toxicity study of aqueous extract of castor bean seeds injected on white mice in 20, 30 and 60 $\mathrm{mg} / \mathrm{Kg}$ of body weight concentrations revealed, infiltration of mononuclear cells in the liver parenchyma and in the dilated sinusoids in $30 \mathrm{mg} / \mathrm{kg}$ concentration; whereas, group treated with $60 \mathrm{mg} / \mathrm{kg}$ aqueous extraction of the castor seeds showed aggregation of mononuclear cells and neutrophils in the liver parenchyma and proliferation of kupffer cells. Akande et al., $2014^{[24]}$, investigated the histological changes in rat exposed to castor bean cake based diets, which showed mild congestion, cellular infiltration and necrosis in the cell of the liver as well. Acute toxicity of ricin administered intraperitoneally in Swiss albino male mice caused severe passive venous congestion with hepatic sinusoidal ectasia in liver [25]. AL-Tamimi and Hegazi (2008) [26] Reported neurological and ophthalmological lesions in human following exposure to castor bean seed. Therefore, the results of the present study is parallel with that of Daprà et al., 2005 ${ }^{[27]}$ who reported encountered histological effects of lectins on the rainbow trout intestine and liver where lectins induced local inflammatory reactions on the intestinal mucosae and normal liver histological pattern with red kidney bean lectins. The results indicated that the vital water quality parameters were not altered much within the short duration of the experimentation. However, dissolved oxygen as critical parameters for aquatic animals including fish drastically reduced with consequent increase in BOD1 in both the toxicants under the present investigation. Both these alterations might have triggered distress to the test fish in the treatments among which respiratory distress of the test fish in MOC treatment was certainly aggravated. Sarkhel and Das (2005) ${ }^{[22]}$ reported such trend in DO and BOD1 following application of MOC as fish toxicant in aquatic medium.

\section{Conclusion}

The histopathological effects upon different tissues clearly indicated castor bean seed as potential toxicant to a number of vital organs in Oreochromis mossambicus. Therefore, toxicological manifestation through CBS treatment was prominent in kidney, gill, intestine and liver though the time taken for first and total mortality was comparatively higher compared to MOC. Though reports on histopathological changes following castor bean seed poisoning in fish is extremely meagre, ${ }^{[26]}$ reported acute and potentially fatal gastroenteritis in addition to neurological and ophthalmological lesions even delayed visceral damages in higher mammals.

\section{Acknowledgement}

The first author acknowledges the Department of Aquaculture, Faculty of Fishery Sciences, West Bengal University of Animal and Fishery Sciences for providing the experimental farm and laboratory facilities and Prof. T. J. Abraham (Department of Aquatic Animal Health, Faculty of Fishery Sciences, West Bengal University of Animal and Fishery Sciences) for providing laboratory facilities for histological analyses.

\section{References}

1. Cagauan AG. The impact of pesticides on rice field vertebrates with emphasis on fish. International Rice Research Institute, Kluwer Academic Publishers 1995, 203-248.

2. Minsalan CO, Chiu YN. Effects of tea seed cake on selective elimination of finfish in shrimp ponds. In: Maclean JL, Dizon IB, Hosillos LV (Eds.). The First Asian Fisheries Forum. Asian Fisheries Society, Manila, Philippines 1986, 79-82.

3. Homechaudhuri S, Banerjee S. Scanning electron microscopic observations on the blood cells of common 
carp (Cyprinus carpio) and catfish (Heteropneustes fossilis) under piscicide toxicity. Asian Fisheries Science. Metro Manila 1991;4(2):263-267.

4. Chen JC, Chen KW. Hemolymph oxyhemocyanin, protein levels, acid-base balance, and ammonia and urea excretions of Penaeus japonicus exposed to saponin at different salinity levels. Aquatic Toxicology 1998; 36(1, 2):115-128. doi: 10.1016/S0166-445X(96)00794-1

5. Doan LG. Ricin: mechanism of toxicity, clinical manifestations, and vaccine development. A review. Journal of Toxicology: Clinical Toxicology 2004;42(2):201-208. doi: 10.1081/CLT-120030945

6. Audi J, Belson M, Patel M, Schier J, Osterloh J. Ricin poisoning: a comprehensive review. The Journal of the American Medical Association 2005;294(18):2342-2351. doi:10.1001/jama.294.18.2342

7. Olsnes $\mathrm{S}$. The history of ricin, abrin and related toxins. Toxicon 2004;44(4):361-370. doi: 10.1016/j.toxicon.2004.05.003

8. Johnson RC, Temire SW, Woolfitt AR, Ospina M, Preston KP, Olson CT et al. Quantification of ricinine in rat and human urine: a biomarker for ricin exposure. Journal of Analytical Toxicology 2005;29(3):149-155. doi: 10.1093/jat/29.3.149

9. Baleta FN, Ramos-Castro MM, Canceran MAS. Molluscicidal and piscicidal activities of extracts of castor (Ricinus communis) bean for aquaculture management. Israeli Journal of AquacultureBAMIGDEH 2015;67:1-6.

10. Mondal B, Das SK. Comparative evaluation of mohua (Bassia latifolia) oil cake and castor bean (Ricinus communis) seed as fish toxicants for tilapia (Oreochromis mossambicus) and panchax (Aplocheilus panchax) with residual toxicity assessment on Labeo bata. Aquaculture Research 2019;50(9):2341-2349. doi: 10.1111/are.14115

11. Virchow R. Die Cellular Pathologic in iner Beg rundug quf physiologisdic and Pathologische Gawelichre. Berlin, A. Hirshwald 1958.

12. Bell GR. Glycogen B lactic acid concentration in Atlantic cod Gradus morher in relation to exercise. Journal of Fisheries Research Bd. QQ 1968;25:837-851.

13. Brown VM, Mitrolic UV, Stark GTC. Effects of chronic exposure to zinc on toxicity of a mixture of detergent and zinc. Water Research. Pergamon Press 1968;2:255-263. doi: 10.1016/0043-1354(68)90018-3

14. Tasneem S, Kauser SH, Yasmeen R. Toxicity of two biopesticidal plants aqueous leaf extracts to Oreochromis mossambicus-histopathology of gill, liver and intestine. Journal of Biopesticides 2014;7(2):124-131.

15. Alim D, Matter H. Histopathological Alteration induced in gills of juvenile Nile Tilapia Oreochromis niloticus upon exposure to two bio-pesticides. International Journal of Fisheries and Aquatic Studies 2015;2(5):8083.

16. Mosleh YYI, Afifi M. Molecular, Histological and Biochemical Effects of Tea Seed Cake on Hepatic and Renal Functions of Oreochromis niloticus. Journal of Applied Plant Protection; Suez canal University 2013; 1(1):27-32.

17. El-Murr A, Ali HA, Eldeen NAMN. Molecular, biochemical and histological effects of tea seed cake on different organs of Oreochromis niloticus. Global Veterinaria 2014;13(5):711-719.

doi: 10.5829/idosi.gv.2014.13.05.8693
18. Jhingran VG. Fish and Fisheries of India. Edn 2, Hindustan Publishing Corporation, New Delhi, India 1985, 413.

19. APHA. Standard Methods for the Examination of Water and Waste water. Edn 16, American Public Health Association, American Water Works Association and Water Pollution Control Federation, Washington D.C 1995, 129.

20. EPA. Drinking Water Standards and Health Advisories. Washington: USEPA Office of Drinking Water 2009.

21. Roberts RJ. The parasitology of teleosts. In: Fish Pathology. Edn 3, Blackwell Publishing Limited, New Delhi 2001.

22. Sarkhel C, Das SK. Impact of three piscicides on nitrogen-mineralizing and cellulose-decomposing bacterial populations. Journal of Applied Aquaculture. 2005;16(3, 4):167-182. doi: 10.1300/J028v16n03_12

23. Hassan IA, Al-Awadi AQ, Salman IS, Jasim NN. Histological study of the effect of aqueous extraction of the castor seeds on the internal organs in male white mice. Basrah Journal of Veterinary Research 2016; 14(1):54-65.

24. Akande TO, Odunsi AA, Emiola AO, Adedeji OS. Evaluation of Growth Performance and Hepatic Histological Changes in Albino Rats Fed Varying Levels of Differently Treated Castor Bean Cake Based Diets. Journal of Animal Science Advances 2014;4(1):641-647.

25. Kumar O, Sugendran K, Pant SC, Vijayaraghavan R, Prakash AO. Effect of Ricin on Some Biochemical, Haematological, and Histopathological Variables in Mice. Defence Science Journal 2004;54(4):493-502.

26. AL-Tamimi FA, Hegazi AE. A case of castor bean poisoning. Sultan Qaboos University Medical Journal. 2008;8(1):83

27. Daprà F, Gai F, Palmegiano GB, Prearo M, Sicuro B. Histological and physiological changes induced by Red Kidney Bean lectins in the digestive system of rainbow trout, Oncorhynchus mykiss (Walbaum). Ittiopatologia 2005;2:241-258. 